\title{
Kesadaran Pemahaman Mahasiswa STT-PLN Terhadap Lambang Negara Republik Indonesia
}

\author{
Emillia $^{\mathrm{a}, 1 *}$, Michiel Martin Rumondor ${ }^{\mathrm{b}, 2}$ \\ a,bDiploma III Teknik Mesin, STT-PLN \\ ${ }^{1}$ emilliakobiarek@gmail.com; ${ }^{2}$ mmr070758@gmail.com \\ *korespondensi penulis
}

Naskah diterima: 03-12-18, direvisi: 10-04-19, disetujui: 05-08-19

DOI: http://dx.doi.org/10.32493/jpkn.v6i2.y2019.p75-86

\begin{abstract}
Abstrak
Tujuan penelitian ini adalah untuk mengetahui sampai seberapa jauh pemahaman mahasiswa didik terhadap Lambang Negara Republik Indonesia dan rasa nasionalisme yang dimiliki. Tulisan ini menggunakan penelitian yang bersifat eksplanatoris, melakukan observasi lapangan di STT-PLN Jakarta dengan cara melakukan kuisioner pada 243 orang sample mahasiswa dalam Semester Genap Tahun Akademik 2017/2018. Selain itu, dilakukan penelitian kepustakaan dengan mempelajari buku-buku acuan, hasil penelitian dan jurnal Nasional dan peraturan perundangan. Pada kegiatan perkuliahan sehari-hari ditemukan adanya permasalahan bahwa terdapat kurangnya kesadaran pemahaman akan pentingnya Lambang Negara Republik Indonesia pada mahasiswa didik dan rasa cinta tanah air dan nasionalisme terutama pada saat kegiatan upacara Bendera Merah Putih dan menyanyikan lagu Indonesia Raya. Penelitian diharapkan dapat memberikan manfaat bagaimana metode pembelajaran Pendidikan Kewarganegaraan dan Pancasila yang tepat untuk meningkatkan rasa nasionalisme bagi peserta didik menjadi lebih baik.
\end{abstract}

Kata-kata kunci: kesadaran mahasiswa; lambang negara; rasa nasionalisme

\section{Abstract}

The purpose of this study is to find out to what extent students' understanding of the Republic of Indonesia's State Symbol and nationalism. This paper uses explanatory research, conducting field observations at STT-PLN Jakarta by conducting questionnaires on 243 sample students in the Even Semester Academic Year 2017/2018. In addition, library research is carried out by studying reference books, research results and national journals and legislation. In daily lectures there were problems that there was a lack of awareness of the importance of the Republic of Indonesia's National Symbols to students and their love for the motherland and nationalism, especially during the Red and White Flag ceremony and singing the Indonesia Raya song. The research is expected to provide benefits on how the appropriate Citizenship and Pancasila Education learning methods to improve nationalism for students become better.

Keywords: student awareness; state symbol; sense of nationalism 


\section{Pendahuluan}

Berawal pada suatu kegiatan perkuliahan sehari-hari di lingkungan STT-PLN ditemukan adanya kurangmya tingkat kesadaran pemahaman mahasiswa didik terhadap arti Lambang Negara Republik Indonesia. Demikian juga pada saat melakukan kegiatan upacara bendera dan menyanyikan Lagu Kebangsaan Indonesia Raya dirasakan juga bahwa mahasiswa didik kurang memiliki rasa cinta tanah air dan nasionalisme akan pentingnya pemahaman terhadap Lambang Negara Republik Indonesia sebagai warga negara Indonesia yang baik. Apalagi Bendera Merah Putih dan lambang negara lainnya seperti Garuda Pancasila, Bahasa Indonesia dan Lagu Kebangsaan Indonesia Raya yang telah disahkan secara resmi sebagai Lambang Negara Republik Indonesia melalui proses sejarah yang sangat panjang.

Di dalam penelitian ini hanya dibatasi terhadap pemahaman Lambang Negara yang berupa Bendera Kebangsaan Merah Putih dan Lagu Indonesia Raya. Perjalanan sejarah perancangan Lambang Negara Republik Indonesia hampir sama setara usianya dengan perjuangan bangsa ini mengisi kemerdekaan (Turiman, 2014). Seperti yang diketahui bahwa Bendera Kebangsaan Negara Republik Indonesia adalah Bendera Negara, yaitu Sang Saka Merah Putih, Sang Merah Putih atau secara singkat disebut Bendera Merah Putih bahkan disebut juga Sang Dwiwarna (dua warna). Bendera Merah Putih memiliki bentuk empat persegi panjang yang berukuran dengan perbandingan lebar $2 / 3$ dari panjang yang pada bagian atas berwarna merah dan bagian bawahnya berwarna putih yang memiliki ukuran yang sama.

Sebagai warga bangsa yang besar dan generasi penerus sejarah bangsanya, sekaligus umat beriman sudah menjadi kewajiban kita untuk mengangkat kepermukaan fakta dan data sejarah secara jujur dan obyektif (Turiman, Menelusuri "Jejak" Lambang Negara Republik Indonesia Berdasarkan Analisis Sejarah Hukum, 2014). Apabila melihat sejarah masah lampau maka warna merah dan putih tersebut berasal dari warna panji atau Pataka Kerajaan Majapahit yang terletak di Jawa Timur pada abad ke 13. Namun ada sejarah lainnya yang menyebutkan bahwa pemuliaan terhadap warna merah dan putih berasal dari mitologi bangsa Ausironesia mengenai Bunda Bumi dan Bunda Bapak Langit. Keduanya dilambangkan dengan warna merah yang melambangkan tanah dan putih yang melambangkan langit. Oleh karena kedua warna ini merah dan putih selalu terdapat dalam lambang Austronesia dari Tahiti, Indonesia sampai Madagaskar. Kedua warna ini digunakan sebagai simbol dualisme di dalam alam semesta yang selalu saling berpasangan.

Sejarah juga menunjukan bahwa penggunaan bendera merah putih dijumpai dalam Pararaton di mana bala tentara kerajaan Jayakatwang sudah mengibarkan panji-panji yang berwarna merah dan putih pada saat menyerang Kerajaan Singasari. Dengan demikian, maka sebelum berdirinya masa Kerajaan Majapahit pun warna merah dan putih sudah melambangkan panji kerajaan. 
Kerajaan Kediri pun telah menggunakan panji-panji merah putih sebagai lambang Kerajaan Kediri. Demikian juga bendera perang Raja Sisingamangaraja IX dari tanah Batak sudah memakai warna merah putih yang bersimbolkan pedang kembar berwarna putih dengan warna dasar merah terang dan putih. Dua bilah pedang kembar tersebut merupakan simbol piso gaja dompak yang merupakan pusaka Raja Sisingamangaraja I sampai dengan Raja Sisingamangaraja ke XII.

Teknik pembuatan warna merah putih pun sudah dimungkinkan tekstil pewarnaan secara tradisional di Indonesia dahulu. Warna putih berasal dari warna alami kapuk atau tanaman kapas yang kemudian ditenun menjadi selembar kain, sedangkan warna merah berasal dari rebusan daun pohon jati, bunga belimbing wuluh (averrhoa bilimbi) atau dari kulit buah manggis. Masing-masing dicelup ke dalam air rendaman tanaman tersebut.

Pada waktu terjadi peperangan di Aceh, pejuang-pejuang Aceh menggunakan umbul-umbul sebagai bendera perang dengan warna merah putih yang dipadukan dengan lambang pedang bulan sabit, matahari dan bintang serta ayat suci Al Quran. Pada zaman Kerajaan Bugis dan Bone di Sulawesi Selatan sebelum Arung Palaka, bendera Merah Putih merupakan simbol Kerajaan Bone yang bernama Woromporang. Demikian juga di Bali di mana Kerajaan Badung yang berpusat di Puri Pamecutan juga sudah menggunakan panji yang mengandung warna merah dan putih dan juga hitam. Oleh karena itu berdasarkan uraian tersebut di atas masa kerajaan di Indonesia mulai dari tanah Jawa, Sumatera, Sulawesi dan Bali bahkan mungkin wilayah-wilayah lain sudah menggunakan simbol yang memiliki unsur merah putih.

Kemudian memasuki abad ke 18 yang lebih modern ketika terjadi peperangan di Jawa pada tahun 1825-1830 yang dipimpin Pangeran Diponegoro yang juga sudah memakai panji-panji yang berwarna merah putih dalam peperangannya melawan pemerintah Hindia Belanda. Kemudian warna perah putih ini dihidupkan kembali oleh para mahasiswa dan kemudian para tokoh nasionalis di awal abad 20 sebagai simbol rasa cinta tanah air dan nasionalisme terhadap Belanda.

Bendera Merah Putih yang seperti dikenal sekarang ini digunakan pertama kalinya di tanah Jawa pada tahun 1925. Pada waktu itu pemerintahan kolonial Hindia Belanda mengeluarkan larangan untuk mengibarkan Bendera Merah Putih di seluruh wilayah Indonesia. Kemudian Bendera Merah Putih secara resmi dijadikan sebagai Bendera Kebangsaan Republik Indonesia pada tanggal 17 Agustus 1945 (Nasional, 2009).

Bendera Kebangsaan Republik Indonesia mempunyai makna filosofis yang dalam. Warna merah melambangkan keberanian dan warna melambangkan kesucian. Warna merah merupakan simbol raga manusia, sedangkan warna putih merupakan simbol jiwa atau roh manusia Indonesia. Keduanya saling melengkapi, saling berpasangan antara 
raga dan jiwa atau roh manusia untuk membangun negeri Indonesia.

Lambang negara Republik Indonesia berikutnya yang akan uraikan adalah Lagu Kebangsaan Indonesia Raya. Pengertian Lagu kebangsaan adalah lagu yang menjadi simbol suatu negara yang membedakannya dengan negara lain. Mengenai lagu yang mana yang dapat dijadikan sebagai lambang negara, maka lebih lanjut dapat dilihat di dalam Pasal 58 Undang-Undang No. 24 Tahun 2009 yang berbunyi : "Lagu Kebangsaan adalah Indonesia Raya yang digubah oleh Wage Rudolf Supratman."

Lagu kebangsaan ditetapkan secara resmi menjadi simbol suatu bangsa sehingga membedakanya dengan negara lain seperti yang telah disebutkan di atas dan merupakan satu-satunya lagu resmi suatu negara atau daerah yang menjadi ciri khasnya. Setiap negara di dunia ini memiliki lagu kebangsaannya masingmasing. Lagu kebangsaan itu merupakan suatu pernyataan dan melambangkan citacita nasional bangsa yang bersangkutan. Lagu kebangsaan juga melambangkan perjuangan suatu bangsa dalam mencapai cita-cita nasionalnya dan mempertahankan kemerdekaan dan kehormatan bangsanya.

Lagu Kebangsaan Indonesia dikenal dengan nama lagu "Indonesia Raya" yang juga merupakan simbol perjuangan bangsa Indonesia dalam mencapai dan mempertahankan kemerdekaan negara Indonesia sekaligus merupakan pemersatu bangsa dan tekad bangsa Indonesia. Lagu Indonesia Raya yang dikumandangkan di seluruh wilayah tanah air Indonesia selama perang kemerdekaan di Indonesia merupakan pendorong semangat para pemuda Indonesia untuk bertempur sampai titik darah penghabisan untuk mendapatkan kemerdekaan Indonesia walaupun nyawa menjadi taruhannya dengan hanya menggunakan bambu runcing yang sangat sederhana dalam melawan tentara Hindia Belanda yang pada waktu sudah menggunakan senjata yang jauh lebih modern.

Oleh karena itu bagi bangsa Indonesia, lagu kebangsaan Indonesia Raya dan Bendera Kebangsaan Merah Putih melambangkan kehormatan bangsa dan negara Indonesia. Lagu kebangsaaan memiliki kedudukan yang sakral apabila ditinjau dari sejarahnya sehingga harus dihormati oleh seluruh rakyat Indonesia. Sehingga lagu kebangsaan selalu dinyanyikan atau diperdengarkan pada setiap acara maupun upacara resmi kenegaraan.

Lagu kebangsaan Indonesia Raya mengandung makna yang sangat dalam dan tujuan mengapa dinyanyikannya lagu tersebut. Apabila tidak mengerti makna yang sangat dalam yang terkandung dalam setiap bait lagu Indonesia Raya tersebut, maka mengakibatkan hilangnya arti dan makna lagu kebangsaan tersebut. Hal ini mengakibatkan semakin lemahnyanya jiwa kebangsaan dan rasa nasionalisme cinta akan tanah air dalam kehidupan berbangsa dan bernegara.

Pada penelitian tentang lambang negara ini berpedoman pada UndangUndang Republik Indonesia No. 24 Tahun 2009 tanggal 9 Juli 2009 tentang Bendera, Bahasa dan Lambang Negara serta Lagu 
Kebangsaan yang telah tercatat dalam Lembaran Negara Republik Indonesia Tahun 2009 No. 109 dan Tambahan Lembaran Negara Republik Indonesia No. 5035 yang terdiri atas 9 Bab dan 74 Pasal.

Pada bagian Konsiderans menimbang huruf a tertulis: "Bahwa Bendera, Bahasa dan Lambang Negara serta Lagu Kebangsaan Indonesia merupakan sarana pemersatu, identitas dan wujud eksistensi bangsa yang menjadi simbol kedaulatan dan kehormatan negara sebagaimana diamanatkan dalam Undang-Undang Dasar Negara Republik Indonesia Tahun 1945" dan pada huruf b tertulis: "Bahwa Bendera, Bahasa dan Lambang Negara serta Lagu Kebangsaan Indonesia merupakan manisfestasi kebudayaan yang berakar pada sejarah perjuangan bangsa, kesatuan dalam keragaman budaya dan kesamaan dalam mewujudkan cita-cita bangsa dan Negara Kesatuan Republik Indonesia."

Faktor-faktor yang dapat mempengaruhi sikap dapat berupa pengalaman pribadi, pengaruh orang lain yang dianggap penting, pengaruh kebudayaan, media massa baik cetak maupun elektronik, lembaga pendidikan dan lembaga agama dan pengaruh faktor emosional lainnya. Di samping itu indikator pengukuran sikap dapat dilakukan dengan menilai pernyataan sikap seseorangyang berupa rangkaian kalimat yang mengatakan sesuatu mengenai objek setiap yang hendak diungkap.

Pernyataan sikap dapat berisi hal-hal yang positif mengenai suatu objek, yaitu kalimat yang bersifat mendukung atau memihak pada objek sikap disebut dengan pernyataan yang favorable. Sebaliknya pernyataan sikap mungkin pula berisi halhal yang negatif yang bersifat tidak mendukung maupun kontra terhadap objek sikap yang disebut dengan pernyataan tidak favorable. Suatu skala sikap yang baik harus diusahakan memiliki pernyataan favorable dan tidak favorable dalam jumlah yang seimbang. Dengan demikian pernyataan yang disajikan secara berimbang mengandung unsur positif dan negatif yang seolah-olah memihak atau tidak mendukung sama sekali objek sikap.

Oleh karena itu dapat disimpulkan bahwa rasa nasionalisme yang dimiliki setiap warga negara adalah cerminan rasa cinta tanah air yang tinggi terhadap negaranya yang manifestasinya nampak pada; 1) Kesadaran seseorang sebagai anggota atau warga negara suatu bangsa; 2) Kebanggaan seseorang terhadap negaranya sendiri; 3) Kecintaan seseorang terhadap bangsanya; 4) Kesetiaan dan ketaatan seseorang terhadap negara dan bangsanya; 5) Perjuangan seseorang bagi kepentingan negara dan bangsanya; dan 6) Kerelaan berkorban bagi Negara dan bangsanya.

Dikarenakan kurangnya kesadaran pemahaman mahasiswa di lingkungan STT-PLN terhadap lambang negara seperti yang telah diuraikan di atas, maka pembahasan dalam tulisan ini hanya dibatasi pada sikap pada saat menaikkan Bendera Kebangsaan Republik Indonesia dan pada saat menyanyikan lagu kebangsaan Indonesia Raya. Dengan demikian maka yang menjadi pokok permasalah dalam tulisan ini adalah 
sampai sejauh mana pemahaman kesadaran mahasiswa tersebut terhadap Lambang Negara Republik Indonesia.

Oleh sebab itu yang tujuan dan manfaat penelitian ini adalah agar mahasiswa didik mampu mengembangkan sikap-sikap sebagai berikut; 1) Mengembangkan sikap dan perilaku kewarganegaran yang mengapresiasi nilainilai moral, etika dan sikap tingkah laku dan religius; 2) Menjadi warga negara yang cerdas berkarakter, menjunjung tinggi nilai kemanusian; 3) Menumbuhkembangkan jiwa dan semangat nasionalisme dan rasa cinta pada tanah air termasuk juga pada Lambang Negara Republik Indonesia; 4) Mengembangkan sikap demokratik berkeadaban dan bertanggungjawab serta mengembangkan kemampuan kompetitif bangsa di era globalisasi; dan 5) Menjunjung tinggi nilai-nilai keadilan (Nugroho, Anugrah, \& Nora, 2015).

\section{Metode}

Penelitian ini bersifat eksplanatoris dimana penelitian lapangan dilakukan pada mahasiswa STT-PLN Jakarta dari tiga jurusan yaitu : Jurusan Teknik Mesin, Jurusan Teknik Sipil, Jurusan Teknik Informatika dalam Semester Genap Tahun Akademik 2017/2018 yang melibatkan 243 orang sample mahasiswa.

Pada awal perkuliahan dilakukan observasi awal dengan memberikan kuisioner tertulis untuk mengetahui tingkat pemahaman mahasiswa terhadap Lambang Negara yang diperoleh selama menempuh pendidikan sebelumnya, baik ditingkat Sekolah Menengah Pertama
(SMP) maupun Sekolah Menengah Atas (SMA). Kemudian dilakukan proses pembelajaran dengan metode yang menarik agar kemampuan mahasiswa terhadap pemahaman Lambang Negara Republik Indonesia bertambah. Oleh karena itu dalam penelitian itu diharapkan dapat mengungkapkan juga kendalakendala atau hambatan-hambatan bagi mahasiswa didik dalam memahami pentingnya akan Lambang Negara Republik Indonesia.

Penelitian ini juga menggunakan data primer berupa hasil kuisioner yang dilakukan terhadap mahasiswa didik dan data sekunder dan tersier berupa bukubuku dan jurnal. Sedangkan penelitian hukum dilakukan secara normatif terhadap peraturan perundangan yang berlaku saat ini.

Metode analisa data yang dipergunakan adalah memakai metode pendekatan secara kualitatif melalui pemberian kuisioner kepada 243 orang sample mahasiswa tersebut untuk mencari jawaban atas pertanyaanpertanyaan kuisioner tersebut dan juga kemampuan mempelajari jenis informasi yang didapat dari kuisioner tersebut, sehingga mampu menyimpulkan informasi untuk suatu analisa yang bermakna. Informasi yang terkumpul berupa hasil observasi dan kuisioner selama perkuliahan. Setelah data terkumpul akan disusun menjadi laporan penulisan hasil penelitian yang sistimatis.

\section{Hasil dan Pembahasan}

Penelitian tahap awal dilakukan pada saat tatap muka di awal perkuliahan yang 
terdiri atas delapan kelas kuliah Pendidikan Pancasila, Pendidikan Kewarganegaraan dan Hukum dan Peraturan yang melibatkan 243 orang sample mahasiswa yang berasal dari lulusan Sekolah Menengah Atas (SMA) di Jakarta maupun dari luar Jakarta. Dalam tahap observasi disusun beberapa pertanyaan dalam bentuk tugas tertulis individual yang ditujukan kepada 243 orang sample mahasiswa didik tersebut. Tugas tersebut harus dikerjakan secara essay oleh 243 orang sample mahasiswa dan harus diserahkan kembali untuk dilakukan penilaian terhadap tugas yang dikerjakan oleh 243 orang sample mahasiswa tersebut.

Hasil dari observasi dan penilaian tugas terhadap 243 orang sample mahasiswa yang dapat dilihat dalam tabel yang disajikan berikut ini :

Tabel 1. Hasil Evaluasi Kuisioner

\begin{tabular}{|c|c|c|c|c|c|}
\hline \multirow[t]{2}{*}{ No. } & \multirow[t]{2}{*}{ Daftar Pertanyaan } & \multicolumn{4}{|c|}{$\begin{array}{l}\text { Hasil Penilaian Atas Jawaban } \\
243 \text { Orang Sample Mahasiswa }\end{array}$} \\
\hline & & Baik & Sedang & Cukup & Kurang \\
\hline 1. & $\begin{array}{l}\text { Sebutkan jati diri bangsa Indonesia dan } \\
\text { identitas negara kesatuan Republik } \\
\text { Indonesia yang merupakan cerminan } \\
\text { kedaulatan negara di dalam tata pergaulan } \\
\text { dengan negara-negara lain dan menjadi } \\
\text { cerminan kemandirian dan eksistensi } \\
\text { negara Republik Indonesia yang merdeka, } \\
\text { bersatu, berdaulat, adil dan makmur! }\end{array}$ & 17 & 20 & 49 & 156 \\
\hline 2. & $\begin{array}{l}\text { Jelaskan pengertian jati diri bangsa } \\
\text { Indonesia dan identitas Negara Kesatuan } \\
\text { Republik Indonesia sebagaimana dimaksud } \\
\text { pada angka } 1 \text { (satu) di atas }\end{array}$ & 4 & 5 & 40 & 192 \\
\hline 3. & $\begin{array}{l}\text { Jelaskanlah bagaimana sikap tubuh pada } \\
\text { saat anda menyanyikan lagu kebangsaan } \\
\text { Indonesia Raya! }\end{array}$ & 9 & 25 & 115 & 92 \\
\hline 4. & $\begin{array}{l}\text { Jelaskanlah bagaimana sikap tubuh anda } \\
\text { pada saat Bendera Merah Putih dinaikan } \\
\text { dan diturunkan! }\end{array}$ & 9 & 20 & 116 & 96 \\
\hline 5. & $\begin{array}{l}\text { Jelaskanlah apakah lagu Kebangsaan } \\
\text { Indonesia Raya dan Bendera Merah Putih } \\
\text { penting bagi anda! }\end{array}$ & 12 & 23 & 87 & 12 \\
\hline
\end{tabular}


Selanjutnya dari tabel yang disajikan tersebut di atas, nampak jelas bahwa, hasil evaluasi kuisioner pertanyaan pertama bahwa komponen yang mewakili penilaian tingkat "kurang" sangat dominan atau besar sekali, yaitu sebanyak 156 orang sample, hanya sedikit yang mewakili komponen penilaian tingkat "baik", yaitu sebesar 17 orang sample dan tingkat "sedang", yaitu 20 orang sample dan komponen penilian tingkat "cukup" sebesar 49 orang sample. Sehubungan dengan hal tersebut, maka terlihat jelas bahwa tingkat pemahaman terhadap pertanyaan pertama yang diajukan di dalam kuisioner pada 243 orang sample mahasiswa tersebut sangat kurang sekali dan hanya ada 1 orang yang tidak dapat menjawab pertanyaan 1 tersebut.

Hasil evaluasi kuisioner pertanyaan kedua bahwa komponen yang mewakili penilaian tingkat "kurang" lebih dominan atau besar apabila dibandingkan dengan hasil kuisioner pertanyaan pertama, yaitu sebesar 192 orang sample, hanya sedikit sekali yang mewakili komponen penilaian tingkat "baik", yaitu sebesar 4 orang sample dan tingkat "sedang", yaitu sebesar 5 orang sample. Sedangkan komponen yang mewakili penilaian tingkat "cukup", yaitu sebesar 40 orang sample. Sehubungan dengan hal tersebut, maka terlihat jelas bahwa tingkat pemahaman terhadap pertanyaan kedua lebih buruk dibandingkan dari pada hasil pertanyaan pertama yang diajukan di dalam kuesioner pada 243 orang sample mahasiswa tersebut dan ada 2 orang yang tidak dapat menjawab pertanyaan 2 .
Hasil evaluasi kuisioner pertanyaan ketiga memiliki perbedaan yang lebih mencolok dengan hasil kuisioner pertanyaan pertama dan kedua, dimana komponen penilaian tingkat "kurang", yaitu sebesar 92 orang sample dan yang mewakili komponen penilaian tingkat "cukup", yaitu sebesar 115 orang sample yang artinya bahwa tingkat pemahaman 243 orang sample mahasiswa pada pertanyaan ketiga jauh lebih baik dibandinkan hasil dari pada jawaban pertanyaan pertama dan pertanyaan kedua. Hanya sedikit sekali yang mewakili komponen penilaian tingkat "baik", yaitu sebesar 5 orang sample dan komponen penilaian tingkat "sedang", yaitu sebesar 25 orang sample hanya ada 2 (dua) orang yang tidak dapat menjawab pertanyaan 3 (tiga).

Hasil evaluasi kuisioner pertanyaan keempat, bahwa pola yang terdapat di dalam hasil kuisioner ini hampir sama dengan pola yang terdapat dalam hasil kuisioner pertanyaan ketiga tersebut di atas karena memang jumlah tingkat penilaian tidak banyak jauh berbeda di mana terlihat bahwa komponen yang mewakili penilaian tingkat "kurang", yaitu 96 orang sample dan yang mewakili komponen penilaian tingkat "cukup" keduanya dalam jumlah yang besar yaitu sebesar 116 orang sample, artinya bahwa tingkat pemahaman 243 orang sample mahasiswa pada pertanyaan keempat jauh lebih baik dibandingkan dari pada hasil jawaban pertanyaan pertama dan pertanyaan kedua. Hanya sedikit sekali yang mewakili komponen penilaian "baik", yaitu 9 orang sample dan 
komponen penilaian tingkat "sedang", yaitu sebesar 20 orang sample dan hanya ada 2 orang yang tidak dapat menjawab pertanyaan 4 .

Hasil evaluasi kuisioner pertanyaan kelima yang merupakan pertanyaan yang terakhir berikut ini, yaitu : memiliki pola yang hampir sama dengan pola yang terdapat dalam hasil evaluasi pertanyaan keempat 4 tersebut di atas karena memang jumlah tingkat penilaian tidak banyak jauh berbeda di mana terlihat bahwa yang mewakili komponen penilaian tingkat "kurang", yaitu sebesar 12 orang sample dan yang mewakili komponen penilaian tingkat "cukup", yaitu sebesar 87 orang keduanya dalam jumlah yang besar yang artinya bahwa tingkat pemahaman 243 orang sample mahasiswa pada pertanyaan kelima kurang baik dibandingkan dari pada hasil jawaban pertanyaan keempat tersebut di atas. Hanya sedikit sekali yang mewakili komponen penilaian tingkat "baik", yaitu sebesar 12 orang dan tingkat "sedang", yaitu sebesar 23 orang sample dan 243 orang sample mahasiswa semuanya dapat menjawab pertanyaan kelima.

Selanjutnya berdasarkan pengamatan yang didapat pada saat lagu Indonesia Raya diperdengarkan pada acara Dies Natalis STT-PLN tanggal 24 April lalu yang terdiri dari mahasiswa dan dosen dari berbagai jurusan menunjukan kurangnya kesadaran mereka akan pentingnya Lagu Indonesia Raya. Sikap nasionalisme pada sekarang ini tidak terlihat lagi dalam menyanyikan lagu kebangsaan maupun saat upacara bendera. Banyak warga dan banyak para mahasiswa yang tidak memperlihatkan sikap hormat secara fisik, ketika menyanyikan atau mendengarkan lagu Indonesia Raya. Padahal saat menyanyikan lagu kebangsaan Indonesia Raya diharapkan dapat memperlihatkan sikap fisik yang sesuai dengan peraturan yang telah dibuat. Kenyataan ini menunjukan bahwa pendidikan kurang memberikan bobot tentang materi nasionalisme, kurang menanamkan jiwa kebangsaan, kurang melatih membiasakan diri untuk bersikap menghormati lambang-lambang negara, sehingga mereka kurang bangga memiliki bangsa yang merdeka dan kurang bangga memiliki lagu kebangsaan. Padahal pendidikan di Indonesia, sejak awal kemerdekaan menganut paham ajaran $\mathrm{Ki}$ Hajardewantara yang sangat erat dengan nilai-nilai perjuangan dan nilai-nilai nasionalisme.

Apalagi sekarang banyak temuan di lapangan bahwa mahasiswa banyak yang tidak hafal dengan lagu Kebangsaan Indonesia Raya jelas ini merupakan hal yang cukup memprihatinkan bagi bangsa dan bagi dunia pendidikan. Fenomena demikian merupakan salah satu wujud dari lunturnya kecintaan generasi muda terhadap bangsanya. Dari pihak pendidik juga sudah semestinya bisa memberikan contoh bersikap dan arahan pada mahasiswa bahwa lagu kebangsaan itu merupakan salah satu identitas bangsa. Sehingga mahasiswa itu tidak hanya diberi suguhan budaya barat setiap harinya. Institusi pendidikan merupakan tempat yang dapat digunakan untuk menumbuhkan rasa cinta tanah air bagi anak didik. Salah satunya dengan 
menyanyikan lagu kebangsaan secara langsung, mahasiswa diharapkan dapat menjiwai nilai-nilai yang terkandung dalam lagu itu sehingga memunculkan semangat dan jiwa kebangsaan.

Hal ini sesuai dengan UndangUndang No. 24 Tahun 2009 Tentang Bendera, Bahasa Dan Lambang Serta Lagu Kebangsaan pada Pasal 62 yang berbunyi : "Setiap orang yang hadir pada saat lagu kebangsaan diperdengarkan dan/atau dinyanyikan, wajib berdiri tegak dengan sikap hormati." Di dalam pasal ini diharapkan akan membentuk sikap nasionalisme pada siapa saja yang menyanyikanya atau mendengarkan lagu kebangsaan Indonesia Raya. Institusi pendidikan merupakan tempat yang dapat digunakan untuk menumbuhkan rasa cinta tanah air bagi anak didik. Salah satunya dengan menyanyikan lagu kebangsaan Indonesia Raya secara langsung, mahasiswa diharapkan dapat menjiwai nilai-nilai yang terkandung dalam lagu itu sehingga memunculkan semangat dan jiwa kebangsaan.

Undang-Undang No 24. Tahun 2009 yang disahkan pada tanggal 9 Juli 2009 merupakan sebuah Undang-Undang yang secara umum terdiri atas 9 Bab dan 74 Pasal yang pada pokoknya mengatur dan melindungi tentang identitas bangsa Indonesia tentang praktek penetapan dan tata cara penggunaan bendera, bahasa dan lambang negara serta lagu kebangsaan berikut ketentuan-ketentuan pidananya. Di dalam pasal 65 tertulis bahwa : "Warga Negara Indonesia berhak dan wajib memelihara, menjaga dan menggunakan Bendera Negara, Bahasa Indonesia dan Lambang Negara serta
Lagu Kebangsaan untuk kehormatan dan kedaulatan bangsa dan negara sesuai dengan undang-undang ini."

Tujuan dibentuknya Undang-Undang No. 24 Tahun 2009 ini yaitu; 1) Memperkuat persatuan dan kesatuan bangsa dan Negara Kesatuan Republik Indonesia; 2) Menjaga kehormatan yang menunjukkan kedaulatan bangsa dan Negara Kesatuan Republik Indonesia; dan 3) Menciptakan ketertiban, kepastian dan standarisasi penggunaan bendera, bahasa dan lambang negara serta lagu kebangsaan.

Dengan adanya tujuan-tujuan tersebut menjelaskan bahwa sebagai Warga Negara Indonesia (WNI) maka harus menjaga dan melindungi simbol-simbol identitas tersebut yaitu Bendera, Bahasa dan Lambang Negara serta Lagu Kebangsaan sebagai bentuk kecintaan terhadap negara.

\section{Kesimpulan}

Selanjutnya yang menjadi kesimpulan dalam tulisan ini bahwa kesadaran mahasiswa STT-PLN terhadap Lambang Negara Republik Indonesia kurang dan belum memenuhi ketentuan dalam Undang-Undang No. 24 Tahun 2009 tentang Bendera, Bahasa dan Lambang Negara serta Lagu Kebangsaan.

Oleh karena saran yang dapat diberikan agar para dosen pengampu mata kuliah Pendidikan Pancasila dan Pendidikan

Kewarganegaran menggunakan metode pembelajaran yang meliputi; 1) Menggunakan pendekatan yang berorientasi kepada kepentingan peserta didik dan menempatkan mahasiswa sebagai subjek pendidikan, 
mitra dalam proses pembelajaran dan sebagai individu, anggota keluarga, anggota masyarakat dan warga negara; 2) Metode proses pembelajaran yang mendidik dan dialogis, pembahasan secara kritis analitis, induktif, deduktif dan reflektif melalui dialog kreatif yang bersifat partisipatoris untuk meyakini kebenaran substansi dasar kajian dan motivasi sepanjang hayat; 3) Bentuk aktivitas proses pembelajaran kuliah tatap muka, ceramah, dialog termasuk diskusi interaktif, studi kasus, penugasan mandiri, tugas baca, seminar kelas (presentasi) dan evaluasi proses belajar, stadium generale; dan 4) Motivasi dengan menumbuhkan kesadaran bahwa pembelajaran pengembangan kepribadian merupakan kebutuhan hidup untuk eksis dalam masyarakat global.

Akhir kata tidak dapat dipungkiri bahwa Pendidikan Pancasila dan Kewarganegaraan harus diajarkan kepada setiap warga negara Indonesia dari tingkat pendidikan dasar, menengah dan atas sampai dengan jenjang perguruan tinggi. Pendidikan karakter tidak dapat diberikan secara parsial melainkan harus bersifat graduasi dengan melibatkan seluruh jenjang pendidikan. Pendidikan karakter secara substansif meliputi bidang kognitif (pengetahuan), afektif (kesadaran dan penghayatan) dan psikomotorik (perilaku nyata) pada kehidupan seharihari.

\section{Referensi}

Indonesia. (2009). Pasal 24 UU No. 24 Tahun 2009. Indonesia.

Indonesia. (2009). Pasal 4 UU. No. 24 Tahun 2009. Indonesia.

Indonesia. (2009). Pasal 9 UU No. 4 Tahun 2009. Indonesia.

Maraliana, I., \& Sumaryati. (2013). Studi Kebiasaan Menyanyikan Lagu Kebangsaan Indonesia Raya dan Sikap Nasionalisme Siswa Kelas XI SMA Negeri 2 Yogyakarta. Citizenship, Vol. 2, No. 1, Juli, 1-15.

Nasional, B. P. (2009, Agustus). Mencermati UU No. 24 Tahun 2009Tentang Bendera, Bahasa dan Lambang Negaea Serta Lagu Kebangsaan. Badan Pengembangan Hukum Nasional.

Nugroho, A., Anugrah, D., \& Nora, G. A. L. (2015). Etika Berwarganegara Pendidikan Kewarganegaraan Di Perguruan Tinggi. Bandung: GRAHA ILMU.

Turiman. (2014). Analisis Semiotika Hukum Terhadap Lambang Negara Republik Indonesia. Hukum dan Pembangunan, Tahun ke 44, No. 3 JuliSeptember, 338-372.

Turiman. (2014). Menelusuri "Jejak" Lambang Negara Republik Indonesia Berdasarkan Analisis Sejarah Hukum. Hukum dan Pembangunan, Tahun Ke 44, No. 1, Januari-Maret, 121-169.

Virdianti, P., \& Alrianingrum, S. (20145972). Proses Penetapan Garuda Pancasila Sebagai Lambang Negara Indonesia Tahun 1949-1951. AVATARA, e-jurnal Pendidikan Sejarah, Vol. 2, No. 2 Juni. 
Jurnal Pendidikan Kewarganegaraan

Vol. 6 No. 2 September 2019
Journal of Civics and Education Studies p-ISSN 2302-0865 | e-ISSN 2621-346X

[ halaman ini sengaja dikosongkan ] 